\title{
The fate of biocontrol agents under the European phytopharmaceutical regulation: how this regulation hinders the approval of botanicals as new active substances
}

\author{
Marie-Cécile Vekemans ${ }^{1}$ - Patrice A. Marchand ${ }^{1}$ (D) \\ Received: 30 March 2020 / Accepted: 13 July 2020 / Published online: 4 August 2020 \\ (C) Springer-Verlag GmbH Germany, part of Springer Nature 2020
}

\begin{abstract}
The use of biocontrol agents (BCAs) is growing across the world and in Europe in particular, where novel ways of farming are highly encouraged and implemented. However, although the social pressure is high to increase the number of BCAs in use within the EU, the European plant protection products (PPP) regulation (EC) $\mathrm{N}^{\circ}$ 1107/2009 does not define clearly what BCAs are. Therefore, problems and drawbacks are observed throughout the whole authorisation process. Consequently, this situation impedes drastically the rapid implementation of botanical BCAs and their subsequent use in the field. Previous studies described in detail the fate of BCAs and the current administrative process that leads to their approval. Drawbacks are described for GMOs but surprisingly scarcely for pesticides. Therefore, the present study pinpoints the drawbacks of the approval process of botanical BCAs. To achieve this goal, a comparative study of 5 substances (4 of plant origin and 1 chemical) was performed. This study clearly reveals the present weaknesses and loopholes in the European PPP regulation process. The results of the present study may be useful to initiate and promote a major change in the evaluation and the regulation process of BCAs. This should allow designing a novel and innovative framework enabling the development of future plant protection products according to the sustainable use of pesticides, described in the corresponding (EC) Directive $\mathrm{N}^{\circ}$ 128/2009 (SUD). This work targets farmers, policy makers, NGOs and scientists interested in issues related to this topic.
\end{abstract}

Keywords Plant protection products $\cdot$ Biocontrol agents $\cdot$ Botanicals $\cdot$ Active substances $\cdot$ Regulatory improvements

\section{Introduction}

The BCAs (biocontrol agents) market accounts for 3.6 billion euros worldwide and 900 million euros in Europe. In France,

\section{Highlights}

- There is a strong and increasing public demand for a general use of biocontrol agents.

- Unfortunately, BCAs are not clearly defined within the European plant protection products (PPP) regulation.

- Although BCAs are nevertheless considered as active substances, the approval pathway is strictly identical to that for synthetic chemicals and acts as a brake for mixtures of substances, especially botanicals.

- Consequently, this drawback which occurs during the regulation process is seriously hindering the implementation and the field use of botanical BCAs.

Responsible Editor: Giovanni Benelli

Patrice A. Marchand

patrice.marchand@itab.asso.fr

1 Institut de l'Agriculture et de l'Alimentation Biologiques (ITAB), 149 rue de BERCY F-75595, CEDEX 12 Paris, France
$8 \%$ of the plant protection market deals with BCAs. This represents 170 million of euros (IBMA 2018). With a $20 \%$ annual growth and the current steady increase of market demand for BCAs products, BCAs are a now very attractive and growing business sector (Ravensberg 2015).

Although the notion of BCAs is clearly defined at the European and national levels, currently no obvious definition of this concept is observed within the European plant protection products (PPP) regulatory process (Pavela 2016). For example, the Article L253-6 of the rural French code "Code Rural et de la Pêche maritime" defines the BCAs as "agents and products that use natural mechanisms in the context of a holistic fight against pests". In the European Union, BCAs are listed under 4 pillars, namely, macroorganisms, microorganisms, semiochemicals and substances of natural origin including botanicals. All are active substances established under the (EC) No 1107/2009 regulation and listed under the (EC) No 540/2011 regulation except macroorganisms that are not regulated at the European level (Robin 2018; Robin and Marchand 2020). Also, four types of active substances are 
listed under the European PPP regulation, respectively, candidates for substitution, active, low-risk and basic substances. All these substances are defined based on criteria of articles 24, 4, 22 and 23, respectively, of the (EC) No 1107/2009 regulation. Basic substances benefit from a simplified procedure and an unlimited time of approval (Marchand 2015). They are listed under Annex IV of the (EC) No 396/2005 regulation. This means that no MRL (maximum residue limit) is attached to them (Marchand 2016). Due to these characteristics, they are playing an increasingly important role in the implementation of BCAs (Robin 2018). Currently, 20/21 of the approved basic substances fit the BCAs definition, and the use of 18 of them is approved for organic agriculture (Marchand 2017).

Committed by the desire to develop substances, as they are perceived as less toxic than synthetic phytosanitary chemical substances, different stakeholders such as the IBMA (International Biocontrol Manufacturers Association) and some institutes such as ITAB (the Organic Food and Farming Institute) support the evolution of BCAs at the European level (Villaverde et al. 2014).

However, even though Charon et al. (2019) showed that the demand for products devoid of MRLs (like most BCAs) has steadily increased, the number of biocontrol substances approved has increased at a much slower pace. Previous studies have described the fate of BCAs and the process of approval of these substances (Robin and Marchand 2019a; Robin and Marchand 2019b). The present paper aims at pointing out the hurdles observed within the European approval process, even though the public demand for BCAs is high and rapidly increasing.

\section{An increasing public demand for BCAs}

The current awareness of environmental issues related to phytosanitary products (PPP) and residues testifies a crucial need for less toxic substances and devoid of MRLs, as defined by the European Chemical Agency (ECHA). This should necessarily translate into an increase of the use of BCAs. Indeed, generally, the lower the MRL, the higher is the toxicity. Nevertheless, some substances without MRLs including most BCAs are listed (133 out of 200) under Annex IV of the regulation (EC) No 396/2005 (i.e. substances with no MRL). Briefly this means that residues are not a concern. Thus, they are not investigated. To obtain an approval, a special request needs to be made. Indeed, these substances are temporarily listed under Annex V of the same regulation (MRL by default) after approval (Robin and Marchand 2019a). Following approval of the substance an additional report is required to obtain the inclusion under the Annex IV (no MRL). Then, a vote on the MRL is performed during the same PAFF Committee as is the case for synthetic agrochemical protectants meeting (Standing Committee on Plants, Animals, Food and Feed).
Yet, some substances are directly included under Annex IV during approval. For example, most of the substances from animal and plant origin benefit from this bypass (Charon et al. 2019).

\section{The present regulation has a negative impact on progress}

The BCAs' concept is not clearly defined or described within the European PPP regulations. All active substances are regulated at the European level by Regulation (EC) No $1107 / 2009$, which grants market approval on phytosanitary products. As opposed to Directive No 91/414/EEC, the implementation of this regulation is favourable to BCAs because of their eco-toxicological criteria, and the fact that the depth of the evaluation of these products was strengthened (Robin 2018).

However, even though with the full implementation of Directive (EC) No 2009/128, the European Union is currently interested in taking actions to support the sustainable use of phytosanitary products; the PPP regulation is not encouraging the use or uptake of BCAs (Charon et al. 2019). For instance, since 2018, only 5 new biocontrol substances were approved. Indeed, the former Directive (EC) No 91/414/EEC, aiming at standardizing the phytosanitary products, has impeded the uptake of substances from natural origin because the rate of return and approval fees is too high for applicants (Matyjaszczyk 2011). Moreover, the decision criteria mainly focus on chemical substances, including criteria for low-risk substance in Annex II (European Commission 2017a). As a consequence, BCAs, such as microorganisms, were not approved as frequently as might have been expected (Alabouvette et al. 2006). Fortunately, different guidelines, such as SANCO/12545/ 2014-rev.2 concerning the microorganisms and SANCO/ 11470/2012-rev.8 concerning botanicals, were established recently to make their approval easier (European Commission 2014). Finally, the European parliament published the PEST report giving an injunction to the Commission to modify the regulation in order to facilitate the market access to BCAs (European Parliament 2018).

Amongst all these hurdles, one major concern is the approval process for substances, which is very cumbersome. First, a file is compiled for each substance according to the requirements defined by the regulation (EU) No 283/2013. Then, this is transmitted to the Rapporteur Member State (RMS) to each national agency that then reports on the file to the EFSA after first evaluation. Since new EU rules published 24th November 2009 in the official journal of the European Union, a co-rapporteur is also required (European Parliament 2009). After the approval of a substance, the European Member States (MS) can deliver a market authorisation for their national market. This process appears smooth; however, in practice it frequently meets with 
misunderstanding, generates misinterpretations and leads to over prevention due to the great number of molecules contained in these botanicals. As a result, it leads to a nonapproval of biocontrol substances, even though they are safe and a very strong demand for them by the public exists (Robin and Marchand 2019a), and are in line with other overarching EU objectives for achieving a more sustainable form agriculture. This paper aims to reveal the hurdles encountered during the regulation process in order to improve its effectiveness and encourage the design of a novel framework to support the development, implementation and use of botanical BCAs.

\section{Material and methods}

\section{Material and data}

\section{European pesticides database}

The raw data were retrieved from the European pesticides database. This database lists all the substances approved as well as those not approved and those where an approval is pending (European Commission 2020a).

\section{Review and draft assessment reports on substances}

The toxicological data and the EFSA outcomes on substances applications were retrieved from reports made by the EFSA and those submitted by the rapporteurs (European Commission 2008; European Food and Safety Authority 2008; Marrone Bio Innovations 2009; European Food and Safety Authority 2013; European Commission 2014; European Food and Safety Authority 2015; Azab et al. 2017; European Food and Safety Authority 2017; ITAB 2017, 2018; European Food and Safety Authority 2018a, b, c; European Commission 2019a; European Food and Safety Authority 2019).

\section{Implementing regulation decisions}

The implementing regulations decisions of five substances, namely, Reynoutria sachalinensis (Chemical Abstracts Service (CAS) number attached to five key components: Resveratrol: 501-36-0, Resveratrol glucoside: 65914-17-2, Emodin: 518-82-1, Emodin glucoside: 38840-23-2, Physcion: 521-61-9), beer (CAS* number: 8029-31-0), grape Vitis vinifera cane tannins (CAS* number: 84929-27-1), pyrethrins (CAS* number: 8003-34-7) and mefentrifluconazole (CAS* number: 1417782-03-6) were retrieved (European Commission 2013, 2018a, b, 2019b, 2020b). These regulations detail the conclusion concerning the approval or non-approval of each substance. Beer, pyrethrins and mefentrifluconazole were approved, whereas grape cane tannins (Vitis vinifera) and knotweed extract (Reynoutria sachalinensis) were not. All the implementing regulation decisions are delivered and signed by the European Commission. Each implementing regulation decision comes with a summary of the evaluation process (review report). The summary starts with the statement of the RMS (Rapporteur Member States) and the applicant. The outcome evaluation of other member states and the EFSA follows. It ends by two articles that specify the approval or nonapproval of the substance as well as the date of entry into force of the regulation.

\section{Methodology}

The chosen substances for this study are either basic or active substance, of chemical or plant origin. From the five considered, three were approved and two were not. Data analyses enabled us to produce two comparative tables summarizing all the substance characteristics. These tables highlight the similarities and differences between the approved and nonapproved substances. Although the natural substances are all botanical BCAs, the chemical substance was chosen by criteria: recently approved (2019) and with fungicide properties as some botanicals. The results of this study are summarized in two tables. These tables were produced using all information available on the substances. Only some data are collected and listed in the Tables 2 and 3. In order to make interpretation and comparison easier, two parts were produced focusing either on the identification (composition, use, application) or the hazard evaluation (residues, toxicology, ecotoxicology, persistence) with corresponding abbreviations in Table 1. More explanations are provided in the following paragraphs.

Primarily, four substances from plant origin were studied. The Grape Vitis vinifera cane tannins is a substance used in nutraceuticals (VINEATROL 30) and for oenological purpose (VineTAn). It is a mixture based on proanthocyanidic (natural pigments) tannins extracted from vine wood, in accordance with the International Oenological Codex (International Organisation of Vine and Wine 2019). The main active component in the mixture is resveratrol. It is currently used as a food ingredient (International Organisation of Vine and Wine 2019). The second substance is beer. The major component is water, and the alcoholic degree is usually around $4 \%$ to $8 \%$, although it may vary between 0.5 and $20 \%$. The production of beer (brewing), involves the fermentation of starches. Beer mainly derived from either malted barley, wheat or maize, and hops. The brewing industry is an important business (ITAB 2017). The third substance, Reynoutria sachalinensis extract, derives from a plant stem from the Polygonaceae family composed of perennial, grasses and rhizomatous plants. The active mixture is a green, brown and cream powder manufactured according to food and pharmaceutical standards. For example, it is used as a food supplement and as a pharmaceutical product (Marrone Bio Innovations 2009). Finally, the last biocontrol substances are 
Table 1 Abbreviations

\begin{tabular}{ll}
\hline Abbreviation & Full description \\
\hline $\mathrm{DT}_{50}$ & $\begin{array}{l}\text { Number of days for which the application of the substance at a certain rate provokes } 50 \% \text { of } \\
\text { death in the experimental group } \\
\text { Concentration of test substance which results in a } 50 \% \text { reduction in biomass growth relative to } \\
\text { the control within } 72 \text {-h exposure. It is regarded as acute }\end{array}$ \\
$\mathrm{E}_{\mathrm{b}} \mathrm{C}_{50}$ & $\begin{array}{l}\text { Concentration of test substance which results in the observation of } 50 \% \text { of the effect } \\
\text { Concentration of test substance which results in a } 50 \% \text { reduction in growth rate relative to the } \\
\mathrm{EC}_{50}\end{array}$ \\
$\mathrm{E}_{\mathrm{r}} \mathrm{C}_{50}$ & $\begin{array}{l}\text { Control within } 72-\mathrm{h} \text { exposure. It is regarded as acute } \\
\text { Intake which provokes } 50 \% \text { of deaths in the experimental group }\end{array}$ \\
$\mathrm{LC}_{50}$ & $\mathrm{LD}_{50}$
\end{tabular}

the pyrethrins. Pyrethrin insecticides naturally occur in Chrysanthemum cinerariifolium flowers, a plant commonly found in Europe. The active substance targets the neural system of insects. They have been used as natural insecticide for thousand years even though their toxic effects on humans are high.

Secondly, to study the general framework of the evaluation process, an approved synthetic chemical substance was used as an internal control during this study. To compare the toxicity of these 5 substances, a pairwise analysis was performed. Ratings of potential danger used in the table derive from the GHS protocol (Globally Harmonized System of Classification and Labelling of Chemicals) (United Nations 2017a, b).

\section{Results}

Tables 2 and 3 show the results of the comparative evaluation. The worst candidate in each row of Table 2 is underlined in red when possible (notable values or level of toxicity/eco toxicity). At first glance, red marks are not equally distributed in Table 2. Some of the substance's column, although corresponding to approved active substance at PPP Reg. contain more red than certain non-approved substances (active or basic).

\section{Discussion}

\section{Basic substances}

Beer and cane tannins are basic substances. However, they are respectively approved and non-approved. But both substances have similar ecotoxicological data. Both derive from the production of alcoholic drinks, namely, beer and wine. The oenological tannins presented as a fungicide derive from the cane. Their antioxidant properties are well known. It protects the wine from its ageing process and against some toxic bacteria. However, during the evaluation process of this file, EFSA and other member states requested supplementary data regarding the impact of this substance on the environment, the mammals, the birds and the aquatic species, although such data were not requested for beer. In addition, the EFSA underlined the possible toxicity of cane tannins on children's health in particular with regard to its presumed carcinogenic potential. Yet, this property is well known for beer, even though beer was approved (European Commission 2017c). As shown in the table, both substances show a similar toxicity/ecotoxicity (or even higher for beer (European Food and Safety Authority 2017)); the grape cane (Vitis vinifera) tannin substance was not approved because of its supposed toxicity (European Food and Safety Authority 2018b; European Commission 2020b). As a matter of fact, grape cane (Vitis vinifera) tannins are allowed as feed additive for mammals, whereas beer is of concern, although risk management measures may reduce exposures.

This observation can be extended to other non-approved plant origin substances such as the Origanum vulgare L. essential oil derived from oregano. It is commonly used as a food aroma and well known for its antioxidant, antimicrobial, immunomodulating and anti-inflammatory properties. Nevertheless, it was not approved as a basic substance. The substance was targeted for use as a fungicide, bactericide and insecticide on different crops: potatoes, lettuce, kidney bean, tomato, pear tree, apple tree, citrus tree, kiwi tree, apricot tree, quince tree and grapevine. The objective was to use it as a foliar spray on most of the crops (PHI* was not applicable). Four major components were identified in this oil: carvacrol, thymol, p-cymene and $\gamma$-terpinene. The identification of these components enabled their possible risks and effects to be specifically identified. No severe deleterious effects (genotoxicity, reprotoxicity, neurotoxicity) were encountered concerning thymol and carvacrol, the oil's active components. As a matter of fact, thymol alone has been approved at the European level as a fungicide and is already used in eight European countries. It was granted no MRL under Annex IV, as expected for oils. Oregano essential oil is listed as a GRAS food (generally recognize as safe) in USA and Canada. In Europe it is used as a food additive for the weaned piglet (European Commission 2020c). All the information available provides an overview of the low risk of this substance (ITAB 2016). Yet, the EFSA 


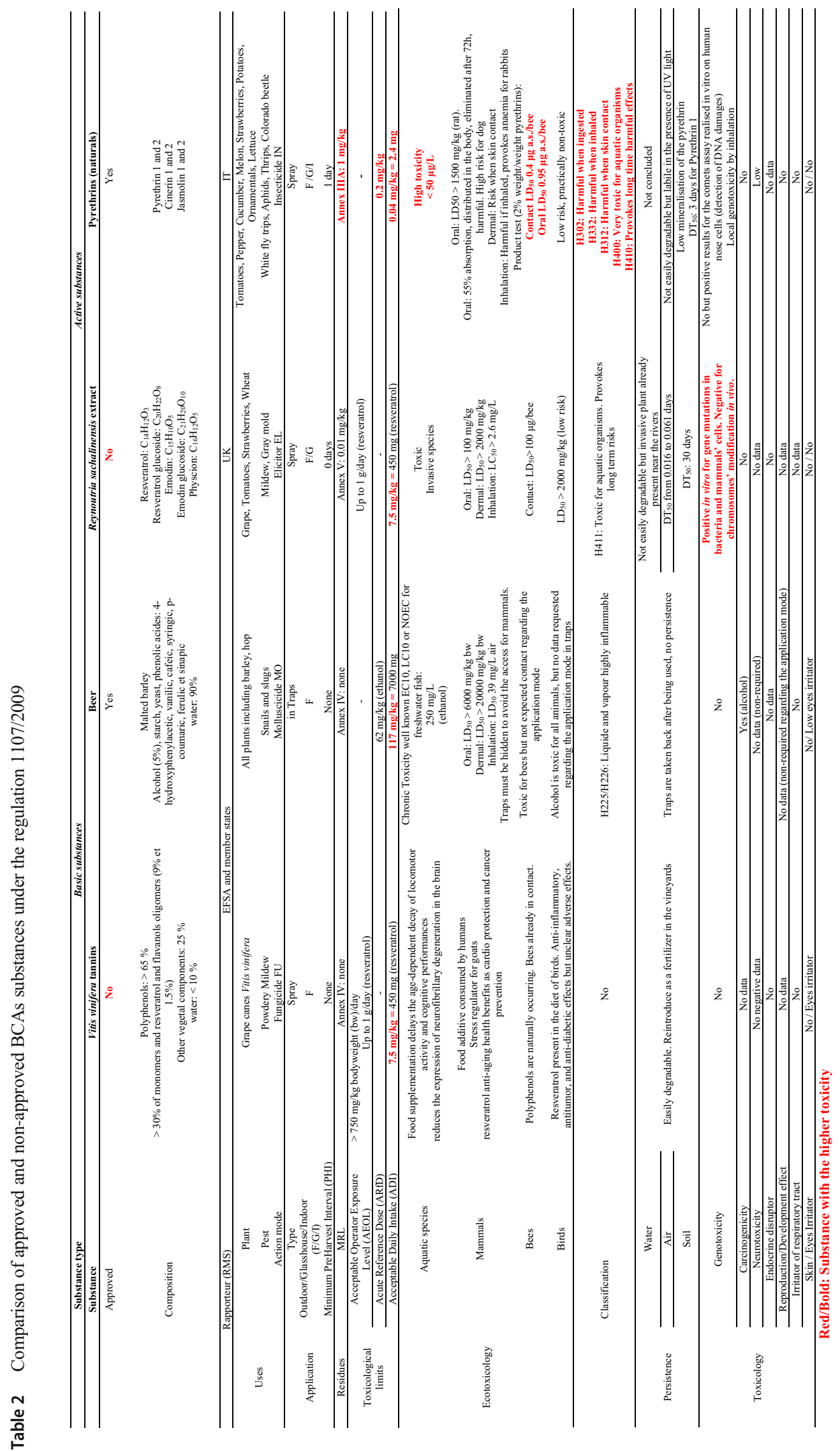


report mentioned that requested rejection of this substance was due to the danger of thymol, which is approved at EU level. Also, some doubt was raised about the oil's pharmaceutical effects, although these are already recognized by the World Health Organization (European Food and Safety Authority 2016). The major issue concerning the evaluation of each substance is that the evaluation process only takes into account every component of the substance, but does not take into account the fact that a mixture may have different properties than each of its constituents alone, due to interactions between them (Andersen et al. 1994). Nevertheless, this substance was not approved (European Commission 2017b).

Finally, although SANCO/11470/2012-rev.8 guideline concerning botanicals (European Commission 2014) clearly mentions basic substances as an issue for botanicals in its Article 16, 11 botanicals proposed as basic substance applications were non-approved.

\section{Botanical active substances}

Pyrethrins and Reynoutria sachalinensis extract are two botanical applicants. From the data, the toxicity of Reynoutria sachalinensis is comparable with the pyrethrins. Yet, the knotweed extract was not approved because of its aquatic toxicity, whereas pyrethrins has received one approval duration extension. Currently pyrethrins are approved in 22 European countries. Knowing that the Reynoutria sachalinensis is an invasive plant, it would have been useful to include it along with botanical BCAs. Some applicant botanical substances were also non-approved, i.e. Decision (EC) No 442/2007 (European Commission 2007). Pyrethrins were not considered by Decision (EC) No 442/2007 and were approved in 2008 (Commission Directive (EC) No2008/ 127), later transferred in Part A of implementing Reg. (EC) No 540/2011 during the implementation of Reg. (EC) No 1107/2009. During the last revision of the approval (SANCO/2627/08) in 2013, ADI, ARfD and AOEL were defined, and further toxicity studies were required (European Commission 2017d). Furthermore, renewal process is ongoing with an extension of the approval period granted in 2017 (European Commission 2017e) until 2022.

\section{Chemical active substances}

Unfortunately, synthetic chemical substances often make their way through this cumbersome process quite easily. Surprisingly, Table 2 shows that a toxic chemical substance, such as mefentrifluconazole, was recently approved under the current regulation (European Commission 2019b). One understands the danger of this substance with a very low MRL when one compares it with other substances in Table 1. This strongly underlines the inconsistent behaviour of the evaluation process with respect to the official desire to increase the number and boost the use of BCAs and low-risk substances. As matter of fact, the EU Parliament has already asked the EU Commission to improve and simplify the regulation process in the PEST report (European Parliament 2018).

\section{Number of botanical extracts concerned by non- approval as substances (active or basic)}

Basic substances Grape (Vitis vinifera) cane tannins, propolis (water-soluble extract), Saponaria officinalis (root extract), Artemisia absinthium L., Origanum vulgare L. essential oil, Satureja montana L. essential oil, Arctium lappa L. (aerial parts), Tanacetum vulgare L., Artemisia vulgaris L., paprika extract (capsanthin, capsorubin E 160 c), Achillea millefolium L., Rheum officinale root extract and citrus pulp were nonapproved, whereas extract of the wood of Quassia amara L., rhododendron honey, Castanea and Schinopsis tannins (European Food and Safety Authority 2018c) and later fermented extract from leaves of Symphytum officinale L. (comfrey) and extract from rhododendron and valerian extract were withdrawn before vote due to damaging EFSA evaluation conclusions, although some are nevertheless approved for food, feed, cosmetic or medicinal purposes.

Active substances Citrus extract/grapefruit seed extract, conifer needle powder, extract from Menta piperita, garlic pulp, marigold extract, onion extract, mustard powder, plant oils/ marjoram oil, plant oils/coconut oil, soybean extract and wheat gluten were not approved at the 4th stage for diverse reasons and more recently Reynoutria sachalinensis extract.

\section{Conclusions}

\section{Conclusion of the study}

This study aims at pointing out the drawbacks of the approval process for botanical BCAs as active substances under the European PPP regulation. It shows clearly that some chemical substances exhibiting similar toxicological data were approved, whereas other botanicals were not. But this study does not reveal all the hurdles encountered throughout the evaluation process, especially for non-single chemical molecules as botanicals. Finally, it is worth noting that no botanical lowrisk substance was approved nor even considered.

Therefore, the present study emphasizes the deficiency existing at the European level regarding an important issue, namely, a strong need to expand new botanical BCAs. In fact, more than 30 applications for promising botanicals have not been approved under EU PPP regulations since 2007. These 
Table 3 Characteristic of a chemical substance approved under the regulation 1107/2009

\begin{tabular}{|c|c|c|}
\hline \multicolumn{2}{|l|}{ Substance } & Mefentrifluconazole \\
\hline \multicolumn{2}{|l|}{ Approved } & Yes \\
\hline \multicolumn{2}{|l|}{ Composition } & $\begin{array}{l}\text { (2RS)-2-[4-(4-chlorophenoxy)-2(trifluoromethyl)phenyl]-1- } \\
\text { (1H-1,2,4-triazol-1yl) propan-2-ol }\end{array}$ \\
\hline \multicolumn{2}{|c|}{ Rapporteur (RMS) } & UK \\
\hline \multirow[t]{3}{*}{ Uses } & Plant & Cereals \\
\hline & Pest & Septoria tritici - SEPTTR \\
\hline & Action mode & Fungicide FU \\
\hline \multirow[t]{3}{*}{ Application } & Type & Foliar spray \\
\hline & $\mathrm{F} / \mathrm{G} / \mathrm{I}$ & F in Northern and Southern EU \\
\hline & PHI & 35 days \\
\hline Residues & MRL & Annexe II: $0.01 \mathrm{mg} / \mathrm{kg}$ \\
\hline \multirow{4}{*}{$\begin{array}{l}\text { Toxicological } \\
\text { limits }\end{array}$} & AOEL & $0.035 \mathrm{mg} / \mathrm{kg}$ bw per day \\
\hline & ARfD & $0.15 \mathrm{mg} / \mathrm{kg}$ bw \\
\hline & ADI & $0.035 \mathrm{mg} / \mathrm{kg}$ bw \\
\hline & $\begin{array}{l}\text { Acute acceptable operator Exposure level } \\
\text { (AAOEL) }\end{array}$ & $0.15 \mathrm{mg} / \mathrm{kg}$ bw \\
\hline \multirow[t]{4}{*}{ Ecotoxicology } & Aquatic species & High toxicity for aquatic organisms, long lasting effects on aquatic life \\
\hline & Mammals & $\begin{array}{l}\text { Toxicity observed when administrated by the oral, dermal or inhalation } \\
\text { routes } \\
\text { Oral: } L D_{50}>2000 \mathrm{mg} / \mathrm{kg}\end{array}$ \\
\hline & Bees & $\begin{array}{l}\text { Contact: } \mathrm{LD}_{50}>200 \mu \mathrm{g} / \mathrm{bee} \\
\text { Oral: } \mathrm{LD}_{50}>100 \mu \mathrm{g} / \mathrm{bee} \\
\text { No chronic risk assessment was done }\end{array}$ \\
\hline & Birds & $\begin{array}{l}\mathrm{LD} 50>816 \mathrm{mg} / \mathrm{kg} \\
\text { Low-risk assessment }\end{array}$ \\
\hline \multicolumn{2}{|l|}{ Classification } & $\begin{array}{l}\text { H315: causes skin irritation. } \\
\text { H317: may cause an allergic skin reaction. } \\
\text { H319: causes serious eye irritation. } \\
\text { H332: harmful if inhaled. } \\
\text { H335: may cause respiratory irritation. } \\
\text { H400: very toxic to aquatic life. } \\
\text { H411: toxic to aquatic life with long lasting effects. }\end{array}$ \\
\hline Persistence & $\begin{array}{l}\text { Water } \\
\text { Air } \\
\text { Soil }\end{array}$ & $\begin{array}{l}\text { High to very high persistence } \\
\mathrm{DT}_{50}: 268 \text { days in soil }\end{array}$ \\
\hline \multirow[t]{7}{*}{ Toxicology } & Genotoxicity & No data \\
\hline & Carcinogenicity & No \\
\hline & Neurotoxicity & No \\
\hline & Endocrine disruptor & No \\
\hline & Reproduction/development effect & No data \\
\hline & Irritator of respiratory tract & Yes \\
\hline & Skin/eyes Irritator & Sensitizer and irritator/irritator \\
\hline
\end{tabular}

pitfalls seriously harm the development of renewable botanical BCAs. We hope this work will trigger some attempts to improve the PPP existing framework for botanicals or to develop a novel plant protection system for a better sustainable agriculture. Recent modification of low-risk substances criteria regarding natural occurring substances may be a positive signal for this (European Commission 2017a).

\section{Possible solutions to improve the evaluation system}

Although, possible ways to overcome these approval struggling are numerous (PPP regulation evolution, evaluation criteria changes, other Regulations dispositions taking in consideration...) some are already being deployed to change these negative issues (Amichot et al. 2018). However, nothing 
really changed through PPP regulation evolution, including "REFIT" evaluation of all EU pesticide legislation (Möhring et al. 2019). First of all, although application renewal is possible after a non-approval by regulatory provision, a few applicants took this opportunity (i.e. Capsicum (Paprika extract (capsanthin, capsorubin E $160 \mathrm{c}$ )) and $R$. sacchalinensis extract) to finally obtain an approval for these substances. The EFSA outcome for Capsicum annuиm L. var. annuит, longum group, and cayenne extract is now released. The decision about its approval or otherwise will be known soon (European Food and Safety Authority 2020).

Secondly, the evolution of evaluation criteria may be another target or approach to improve the narrow evaluation tunnel. Recent modification of low-risk substances criteria regarding natural occurring substances may be a positive signal of such developments (European Commission 2017a). Low-risk substances criteria were also adapted to consider natural substances specifically compared with chemicals in terms of stability, degradation and lifetime in soils. Moreover, some criteria are waived for naturally occurring active substances and substances emitted and used by plants, animals and other organisms.

Concerning basic substances evaluation specifically, the ongoing modification and update of the corresponding guideline (working document SANCO/10363/2012) from rev. 9 to a new revision in 2020 may be a way to progress the approval opportunities, although next botanical extract application as comfrey steeping is proposed for non-approval.

However, considering the essential point of botanicals, that is to say the almost infinite total of molecules, compared with the single molecules usually subject to approval, the system is not yet fit for purpose for this kind of application, in particular if the problem of residues and metabolites of the active substance is included. The best evidence for the capriciousness of the approval process is the approval of the PPP triterpene Mevalone ${ }^{\circledR}$ with three separate active substances (thymol, eugenol and geraniol) instead of a botanical extract with the same molecule content. Finally, if a substance such as Reynoutria sachalinensis containing physcion and resveratrol was approved as an active substance by an international company and is having several market authorizations in different countries and did not obtain approval in EU, then the approval system maybe be more deeply revised or modified.

Acknowledgements The Authors would like to thank Dr. Trevor M. Fenning of Forest Research (UK) for providing the helpful advice on the editing and writing of the manuscript.

\section{References}

Alabouvette C, Olivain C, Steinberg C (2006) Biological control of plant diseases: the European situation. Eur J Plant Pathol 114:329-341
Amichot M, Joly P, Martin-Laurent F, Siaussat D, Lavoir AV (2018) Biocontrol, new questions for ecotoxicology? Environ Sci Pollut Res 25:33895-33900. https://doi.org/10.1007/s11356-018-3356-5

Andersen ME, Berry JK, Carter WH, et al (1994) Toxicology of chemical mixtures : case studies, mechanisms, and novel approaches

Azab M, Khabour OF, Alzoubi KH et al (2017) Assessment of genotoxicity of pyrethrin in cultured human lymphocytes. Drug Chem Toxicol 40:251-255. https://doi.org/10.1080/01480545. 2016.1209679

Charon M, Robin D, Marchand PA (2019) The major interest for crop protection of agrochemical substances without maximum residue limit (MRL). Biotechnol Agron Soc Environ 23:22-29. https://doi. org/10.25518/1780-4507.17666

European Commission (2007) Commission decision of 21 June 2007 concerning the non-inclusion of certain active substances in Annex I to Council Directive 91/414/EEC and the withdrawal of authorisations for plant protection products containing these substances. Off J Eur Union 166:16-23

European Commission (2008) Review report for the active substance pyrethrins $\mathrm{SANCO} / 2627 / 08$ - rev. 1

European Commission (2013) Commission implementing regulation (EU) No 798/2013 of 21 August 2013 amending implementing regulation (EU) No 540/2011 as regards the conditions of approval of the active substance pyrethrins. Off J Eur Union: 1-3

European Commission (2014) Guidance document on botanical active substances used in plant protection products

European Commission (2017a) Commission regulation (EU) No 2017/ 1432 of 7 August 2017 amending Regulation (EC) No 1107/2009 of the European Parliament and the council concerning the placing of plant protection products on the market as regards the criteria for the approval of low-risk. Off J Eur Union: 1-4

European Commission (2017b) Commission implementing regulation (EU) No 2017/241 - of 10 February 2017 - concerning the nonapproval of Origanum vulgare L. essential oil as a basic substance in accordance with regulation (EC) No 1107/2009 of the European Parliament and of the council. Off J Eur Union L36:1-2

European Commission (2017c) Commission implementing regulation (EU) of 14 November 2017 concerning the approval of beer as a basic substance in accordance with Regulation (EC) No 1107/2009 of the European Parliament and of the Council concerning the placing of plant protection products on the market, and amending the Annex to Commission Implementing Regulation (EU) No 540/ 2011. Off J Eur Union L297:22-24

European Commission (2017d) Commission implementing regulation (EU) No 798/2013 of 21 August 2013 amending Implementing Regulation (EU) No 540/2011 as regards the conditions of approval of the active substance pyrethrins. Off J Eur Union L224:9-11

European Commission (2017e) Commission implementing regulation (EU) No 2017/195 of 3 February 2017 amending Implementing Regulation (EU) No 540/2011 as regards the extension of the approval periods of several active substances listed in Part B of the Annex to Implementing Regulation (EU) No 686/2012 (AIR IV renewal programme). Off J Eur Union L31:21-24

European Commission (2018a) Commission regulation (EU) No 2018/ 685 of 3 May 2018 amending Annexes II, III and IV to Regulation (EC) No 396/2005 of the European Parliament and of the council as regards maximum residue levels for abamectin, beer, fluopyram, fluxapyroxad, maleic hydrazide. Off J Eur Union L121:1-3

European Commission (2018b) Commission implementing regulation (EU) No 2018/296 of 27 February 2018 concerning the nonapproval of the active substance Reynoutria sachalinensis extract. Off J Eur Union L56:31-32

European Commission (2019a) Review report for the active substance mefentrifluconazole Finalised in the Standing Committee on Plants, Animals, Food and Feed at its meeting on 25 January 2019 in view 
of the approval of mefentrifluconazole in accordance with Regulation (EC) No 1107/20

European Commission (2019b) Commission implementing regulation (EU) 2019/337 - of 27 February 2019 - approving the active substance mefentrifluconazole in accordance with regulation (EC) No 1107 / 2009 of the European Parliament and of the council concerning the placing of plant pr. Off J Eur Union L60:1-5

European Commission (2020a) EU pesticides database. https://ec.europa. $\mathrm{eu} /$ food/plant/pesticides/eu-pesticides-database/public/?event= homepage\&language $=\mathrm{EN}$. Accessed 2 Mar 2020

European Commission (2020b) Commission implementing regulation (EU) 2020/29 of 14 January 2020 concerning the non-approval of Vitis vinifera cane tannins as a basic substance in accordance with regulation (EC) No 1107/2009 of the European Parliament and of the council. Off J Eur Union L9:1-2. https://doi.org/10.2903/sp. efsa.2018.EN-1414

European Commission (2020c) Commission implementing regulation (EU) 2020/160 of 5 February 2020 concerning the authorisation of the preparation of oregano oil, caraway oil, carvacrol, methyl salicylate and L-menthol as a feed additive for weaned piglets (holder of authorisation biom). Off J Eur Union L34:1-3

European Food and Safety Authority (2008) Conclusion on pesticide peer review of the pesticide risk assessment of the active substance ethanol. EFSA Sci Rep:1-99

European Food and Safety Authority (2013) Conclusion on the peer review of the pesticide risk assessment of the active substance pyrethrins. EFSA Sci Rep 11:1-76. https://doi.org/10.2903/j.efsa. 2013.3032

European Food and Safety Authority (2015) Peer review of the pesticide risk assessment of the active substance Reynoutria sachalinensis extract. EFSA J 13:1-73. https://doi.org/10.2903/j.efsa.2015.4221

European Food and Safety Authority (2016) Outcome of the consultation with Member States and EFSA on the basic substance application for Origanum vulgare L. essential oil for use in plant protection as a fungicide, bactericide and insecticide. EFSA Support Publ:1-54. https://doi.org/10.2903/sp.efsa.2016.en-1054

European Food and Safety Authority (2017) Outcome of the consultation with member states and EFSA on the basic substance application for beer for use in plant protection against slugs and snails. EFSA Support Publ 14:1-30. https://doi.org/10.2903/sp.efsa.2017.en1253

European Food and Safety Authority (2018a) Peer review of the pesticide risk assessment of the active substance BAS $750 \mathrm{~F}$ (mefentrifluconazole). EFSA J 16:1-25. https://doi.org/10.2903/j. efsa.2018.5379

European Food and Safety Authority (2018b) Technical report on the outcome of the consultation with Member States and EFSA on the basic substance application for Vitis vinifera cane tannins for use in plant protection as fungicide on grapevine. EFSA supporting publication 2018:EN-1414. 46 pp. https://doi.org/10.2903/sp.efsa.2018. EN-1414

European Food and Safety Authority (2018c) Technical report on the outcome of the consultation with Member States and EFSA on the basic substance application for Castanea and Schinopsis tannins for use in plant protection as bactericide, fungicide and nematicide. EFSA supporting publication 2018:EN-1363. 64 pp. https://doi. org/10.2903/sp.efsa.2018.EN-1363

European Food and Safety Authority (2019) Outcome of the consultation with member states and EFSA on the basic substance application for Vitis vinifera cane tannins for use in plant protection as insecticide. EFSA Support Publ 16:1-46. https://doi.org/10.2903/sp.efsa.2019. en-1562

European Food and Safety Authority (2020) Outcome of the consultation with Member States and EFSA on the basic substance application of Capsicum annuиm L. var. annuиm, longum group, cayenne extract to be used in plant protection as a repellent to seed-eating mammals and birds. EFSA Support Publ:1-77. https://doi.org/10.2903/sp. efsa.2020.en-1838

European Parliament (2009) Regulation (EC) No 1107/2009 of the European Parliament and of the council of 21 October 2009 concerning the placing of plant protection products on the market and repealing Council Directives 79/117/EEC and 91/414/EEC

European Parliament (2018) Rapport sur la procédure d'autorisation des pesticides par l'Union (2018/2153(INI))

IBMA (2018) Le marché du biocontrôle. https://www.ibmafrance.com/ biocontrole/ \%3E. Accessed 22 Feb 2020

International Organisation of Vine and Wine (2019) INTERNATIONAL O E N O L O G ICA L C O D EX INTERNATIONAL ORGANISATION OF VINE AND WINE

ITAB (2016) Basic substance application-Origanum vulgare L. essential oil

ITAB (2017) Basic substance application-beer

ITAB (2018) Basic substance application-grape cane tannins

Marchand PA (2015) Basic substances: an opportunity for approval of low-concern substances under EU pesticide regulation. Pest Manag Sci 71:1197-1200. https://doi.org/10.1002/ps.3997

Marchand PA (2016) Basic substances under EC 1107/2009 phytochemical regulation: experience with non-biocide and food products as biorationals. J Plant Prot Res 56(3):312-318. https://doi.org/10. 1515/jppr-2016-0041

Marchand PA (2017) Basic substances under EU pesticide regulation: an opportunity for organic production? Org Farm 3(1):16-19. https:// doi.org/10.12924/of2017.03010016

Marrone Bio Innovations (2009) Reynoutria extract ( Reynoutria sachalinensis bioprotectant )

Matyjaszczyk E (2011) Active substances used in plant protection in Poland after the European Union accession. J Plant Prot Res 51: 217-224

Möhring N, Gaba S and Finger R (2019) Quantity based indicators fail to identify extreme pesticide risks. Sci. Total Environ 646:503-523. https://doi.org/10.1016/j.scitotenv.2018.07.287

Pavela R (2016) Presence and perspective of using plant extracts as commercial botanical insecticides and farm products for protection against insects - a review. Plant Prot Sci 52(4):229-241. https:// doi.org/10.17221/31/2016-PPSHistory

Ravensberg W (2015) Crop protection in 2030: towards a natural, efficient, safe and sustainable approach. Pp 1-46

Robin D (2018) Évolution des substances de biocontrôle approuvées depuis 1' entrée en vigueur du règlement ( $\mathrm{CE}) \mathrm{n}{ }^{\circ} 1107 / 2009$

Robin DC, Marchand PA (2019a) Evolution of the biocontrol active substances in the framework of the European pesticide regulation (EC) no. 1107/2009. Pest Manag Sci 75:950-958. https://doi.org/ 10.1002/ps.5199

Robin DC, Marchand PA (2019b) Les substances actives de biocontrôle approuvées en Europe : panorama et évolution. In: Index Acta Biocontrôle. pp 25-30

Robin DC, Marchand PA (2020) Macroorganismes réglementés en France. Innov Agronomiques 2020(79):425-439

United Nations (2017a) Health hazards. In: Globally harmonized system of classification and labelling of chemicals (GHS). pp 115-219

United Nations (2017b) Environmental hazards. In: Globally harmonized system of classification and labelling of chemicals (GHS). pp 219 247

Villaverde J, Sevilla-Morán B, Sandín-España P et al (2014) Biopesticides in the framework of the European pesticide regulation (EC) No. 1107/2009. Pest Manag Sci 70:2-5

Publisher's note Springer Nature remains neutral with regard to jurisdictional claims in published maps and institutional affiliations. 